\title{
Kemampuan Berdialog pada Anak Usia 3 Tahun
}

\author{
Dialogue Ability on Three Year Old Children \\ Ifan Setiawan \\ Universitas Islam Negeri Syarif Hidayatullah Jakarta \\ *email: ifan.setiawan18@mhs.uinjkt.ac.id
}

\begin{abstract}
Diajukan:
03/12/2020

Diterima:

09/07/2021

Diterbitkan:

$13 / 07 / 2021$
\end{abstract}

Histori Artikel:

Penelitian ini bertujuan untuk mendeskripsikan kemampuan berdialog anak usia 3 tahun yang dilihat dari kajian psikolinguistik. Pada saat anak berusia 3 tahun,
bahasa anak mulai berfungsi untuk berkomunikasi. Hal ini dikarenakan pada usia 3 tahun, anak semakin banyak menyimpan pembendaharaan kata dan tuturan anak mulai lebih panjang dan tata bahasanya lebih teratur. Metode yang digunakan dalam penelitian ini menggunakan metode kualitatif. Pengumpulan data pada penelitain ini diambil melalui dialog dengan anak berusia 3 tahun. Teknik dalam pengambilan data menggunakan teknik percakapan antara peneliti dengan subyek berupa isi rekaman yang kemudian dicatat sehingga diperoleh dalam bentuk tulisan. Hasil pada penelitian ini menunjukan bahwa dialog pada anak berusia 3 tahun dapat diucapkan dengan baik, walaupun dalam pengucapan bunyi ada beberapa fonem yang kurang jelas dan hasil ini dipengaruhi oleh faktor keluarga dan lingkungan di sekitar tempat tinggal.

Kata kunci: Kemampuan Berdialog; Faktor Keluarga; Faktor Lingkungan, 3 Tahun

\begin{abstract}
This study aims to describe the dialogue skills of 3 year olds as seen from psycholinguistic studies. By the time the child is 3 years old, the child's language begins to function to communicate. This is because at the age of 3 years, children keep more and more vocabulary and children's speech starts to be longer and the grammar is more regular. The method used in this research uses qualitative methods. Data collection in this study was taken through dialogue with 3 year old children. Techniques in data collection using conversation techniques between researchers and subjects in the form of recording content which is then recorded so that it is obtained in writing. The results in this study indicate that dialogue in children aged 3 years can be pronounced well, although in the pronunciation of the sound there are several phonemes that are less clear and this result is influenced by family and environmental factors around the place of residence.
\end{abstract}

Keywords: Ability to Dialogue; Family Factors; Environmental Factors; 3 Years

\section{PENDAHULUAN}

Bahasa merupakan sistem tanda bunyi yang disepakati untuk digunakan oleh para anggota kelompok masyarakat tertentu dalam bekerja sama, berkomunikasi, dan mengidentifikasi diri (Kushartanti, dkk, 2009 : 3). Dalam Kamus Besar Bahasa Indonesia V, bahasa merupakan media bunyi yang salah satu sifatnya adalah arbitrer, kemudian dipakai oleh suatu masyarakat untuk saling berinteraksi, berhubungan, bekerjasama dan mengenali diri (KBBI V Daring). Dengan sifatnya yang arbitrer, akan menimbulkan beragam pandangan mengenai bahasa. Hal ini menyebabkan, di masing-masing wilayah salah satunya adalah Indonesia memiliki tatanan bahasa beragam yang digunakan untuk 
saling berinteraksi antara yang satu dengan yang lain.

Bahasa merupakan sebuah sistem, artinya bahasa itu bukanlah sejumlah unsur yang terkumpul secara tak beraturan melainkan tersusun secara berurutan sehingga membentuk suatu pola. Bahasa bersifat produktif, artinya sebagai suatu sistem dari unsur-unsur yang jumlahnya terbatas, bahasa dapat dipakai secara tidak terbatas oleh pemakainya. Kemudian, bahasa itu unik. Artinya, tiap bahasa mempunyai sistem yang khas yang tidak harus ada dalam bahasa lain.

Berbahasa erat kaitannya dengan kegiatan komunikasi. Komunikasi berarti, pengiriman dan penerimaan pesan atau berita antara dua orang atau lebih sehingga pesan yang dimaksud dapat dipahami (KBBI V Daring). Oleh karena itu peran bahasa dalam komunikasi manusia sangat penting. Mungkin jika tidak ada bahasa, maka komunikasi akan sulit dilakukan. Tanpa adanya bahasa, manusia tidak dapat berinteraksi dan berkomunikasi dengan orang lain. Oleh karena itu, dalam interaksi pasti ada komunikasi, sedangkan komunikasi ini pasti berkaitan dengan bahasa. Maka dari itu, melalui media bahasa inilah, manusia dapat menyampaikan apa yang dipikirkan untuk saling berinteraksi sebagai makhluk sosial baik secara lisan maupun tulisan.

Sejak lahir, manusia sudah memperoleh bahasa dengan cara berinteraksi di lingkungan sosialnya, terutama keluarga. Hal ini terjadi karena orang tua mulai mengajak bicara pada bayi yang seolah-olah sudah dapat berbicara. Pola yang timbulpun sudah dua arah, dimana orang tua seolah-olah menanggapi reaksi bayi dan mengangap setiap reaksi itu mengandung suatu makna yang perlu ditanggapi. Namun pada awal lahir, seorang bayi belum memiliki kemampuan untuk berdialog atau berbicara dengan orang lain. Seorang bayi hanya bisa mendengarkan pembicaraan yang dilakukan oleh orang-orang disekitarnya. Penguasaan bahasa inilah yang sering kita sebut sebagai bahasa Ibu. Maka dari itu, bahasa menjadi sarana yang penting bagi seorang anak untuk mengungkapkan segala pikiran, perasaan, keinginan dan sebagainya dalam kegiatan komunikasi.
Bahasa digunakan oleh manusia dari mulai usia anak-anak hingga dewasa terus berkembang mengikuti bertambahnya usia seseorang. Oleh karena itu, maka struktur bahasa yang dihasilkan pasti berbeda dan berlangsung secara bertahap. Pada usia anakanak misalnya, seorang anak yang baru lahir belajar bahasa secara alami tanpa kesadaran dan terencana dengan apa yang mereka dengar berupa bunyi.

Menurut Sigel dan Cooking proses pemerolehan bahasa anak digunakan dengan cara anak-anak meyesuaikan serangkaian hipotesis dengan ucapan orang tua sampai dapat memilih kaidah tata bahasa yang sesuai dan sederhana dari bahasa yang bersangkutan (Nuryani, 2013:89). Maka dari itu proses pemerolehan bahasa pada usia anak-anak berlangsung dengan beberapa tahap seperti yang dinyatakan oleh Ellis yaitu: (1) tahapan meniru, pada tahap ini anak-anak menirukan bunyi-bunyian yang mereka dengar ataupun diperdengarkan; (2) memahami makna, pada tahap ini anak-anak mulai mampu memahami makna suatu bunyi; (3) tahap penggunaan kata-kata untuk berkomunikasi, pada tahap ini anak mampu menggunakan kata-kata dalam komunikasi (Nuryani, 2013: 91).

Perkembangan bahasa anak akan sampai menjadi suatu kemampuan berbahasa. Dalam kajian bahasa, terdapat empat keterampilan berbahasa yang harus dimiliki oleh manusia, salah satunya adalah kemampuan berbicara.

Kegiatan berbicara pada hakikatnya biasa digunakan oleh manusia untuk saling berinteraksi satu sama lain, mungkin tak seorangpun yang tak sanggup berbicara dalam sehari. Oleh karena itu, berbicara teramsuk kebutuhan primer setiap manusia yang notabene mengemban istilah sebagai makhluk sosial yang tidak akan hidup tanpa bantuan dari orang lain. Setiap orang tentu dapat menyuarakan pikiran dan perasaannya lewat berbicara. Misalnya saja, jika kita sedang merasakan sakit sehinga kita tidak bisa berjalan sendiri untuk mengambil sesuatu, maka kita akan meminta tolong kepada kerabat dengan cara berbicara untuk mengambilkan sesuatu yang kita butuhkan.

Suhendra memaknai berbicara sebagai suatu proses perubahan pikiran maupun 
perasaan menjadi suatu wujud ujaran. Ujaran yang dimaksud adalah bunyi yang bermakna, karena tidak semua suara yang dicapkan memiliki makna bahasa, misalnya suarau kicauan burung dan suara batuk pada manusia. Sedangkan M. Encarnacion dalam Umi Faiziah memaknai berbicara sebagai bagian dari kehidupan normal manusia, sebuah alat, sebagaimana adanya, bagi interaksi dan saling mempengaruhi antar manusia (Susanti, 2018: 1-2). Kemudian, Abdul Chaer mendefinisikan pengertian berbicara sebagai salah satu kegiatan berbahasa yang bertujuan untuk berkomunikasi. Dimana tujuan komunikasi itu sendiri menurut Kridalaksana adalah berupa sistem lambang bunyi yang sifatnya arbitrer kemudian digunakan oleh sekelompok masyarakat untuk saling bekerja sama, berkomunikasi, dan mengidentifikasi diri (Chaer, 2012: 32).

Dalam kehidupan sehari-hari, banyak aktivitas yang bisa dilakukan dengan berbicara, misalnya bercerita, berdiskusi, wawancara, berpidato dan sebagainya, yang tentu memanfaatkan hubungan timbal balik antara penutur dan petutur, paling tidak dua orang atau lebih yang sering kita sebut sebagai dialog.

Dialog menurut Kamus Besar Bahasa Indonesia V memiliki arti: (1) percakapan (dalam sandiwara, cerita, dan sebagainya); (2) karya tulis yang disajikan dalam bentuk percakapan antara dua tokoh atau lebih (KBBI $\mathrm{V}$ Daring). Dalam kegiatan dialog atau percakapan terdapat dua kegiatan berbahasa yang saling berkesinambungan, yakni menyimak dan berbicara. Pertukaran pembicara menjadi penyimak, atau dari penyimak menjadi pembicara berlangsung secara wajar, sistematis, dan otomatis. Kegiatan dialog ini mengandalkan interaksi antara dua atau lebih pihak. Interaksi keduanya dalam dialog yang beranggotakan dua orang dan bersifat satu arah. Sedangkan proses dialog yang beranggotakan lebih dari dua orang, bersifat multi arah. Misalnya, debat, drama, dan sebagainya. Fungsi utama dari dialog adalah saling bertukar pikiran, menginformasikan sesuatu ataupun merundingkan suatu masalah (Susanti, 2018: 115).
Kemampuan dialog pada setiap manusia, tentu berbeda-beda, dari mulai usia anakanak hingga dewasa. Misalnya, pada usia 3-4 tahun, dimana anak sudah bisa menggunakan banyak kata untuk bercakap-cakap atau berdialog. Dalam kemampuan dialog setiap anak dipengaruhi oleh beberapa faktor baik dari faktor psikologis maupun sosial seperti halnya kemampuan bahasa, karena pada dasarnya setiap orang bisa berdialog dengan adanya pemerolehan bahasa yang kemudian diproses menjadi suatu bahasa sebagai alat untuk berdialog. Oleh karena itu, penulis dalam meneliti kemampuan berdialog pada anak usia 3 tahun harus mellihat juga kemampuan anak dalam konteks psikologi anak, yang mana kajian ini digunakan dalam kajian psikolingustik.

Berkaitan dengan kajian psikolinguistik sebagai ilmu yang belum cukup lama ada dalam kajian bahasa, ada beberapa ahli yang berpendapat mengenai ilmu psikolinguistik. Psikolingustik menurut Dardjowidjojo merupakan ilmu yang mempelajari prosesproses mental yang dilalui manusia dalam berbahasa (Nuryani dan Dona, 2013: 7). Aithion berpendapat, bahwa dalama kajian psikolinguistik terdapat dua kajian inti yang dibahas yakni bahasa dan minda (mind). Berbicara mengenai mind tentu tidak ada yang mampu memahami apa yang ada dalam pikiran manusia, begitupun dengan bahasa, manusia tidak mampu menyelami berjuta-juta bahasa yang tersimpan dalam pikiran manusia. Misalnya saja ketika kita bertutur "Saya akan pergi ke rumah nenek pukul 08.00". Dalam pikiran manusia tentu banyak pilihan kata selain pergi, tapi mengapa dalam tuturan itu manusai menggunakan kata pergi bukan kata yang lain. Oleh karena itu, dalam hal ini manusia tentu sulit untuk memahami mengapa manggunakan pilihan kata untuk melingkapi tuturan tersebut hingga menjadi suatu tuturan yang memiliki makna. Maka, bisa dikatakan bahwa apa yang akan keluar dari pikiran manusia hanya dialah yang bisa mengetahui (Nuryani dan Dona, 2013: 5). Demikian juga hal ini terjadi pada kegiatan bahasa pada anak ketika melakukan dialog/ bercakap-cakap.

Kemampuan berdialog pada anak usia 3 tahun akan terus berkembang, baik dari segi 
Ifan Setiawan

Kemampuan Berdialog pada Anak Usia 3 Tahun

bertambah jelasnya ujaran yang dituturkan, pembendahaaraan kata, hingga sampai membentuk susunan kalimat yang baik dan benar seperti halnya bahasa yang digunakan oleh orang dewasa, sehingga bahasa yang digunakan semakin bervariasi (Aprilia dan Nuryani, 2020). Misalnya, pada usia 0-2 bulan, anak hanya mengeluarkan bunyi-bunyi seperti menangis yang mewakili rasa lapar ataupun merasakan sakit, hingga berkembang sampai tahapan banyak kata diusia 3-6 tahun. Pada tahapan ini, ujaran yang dibunyikan oleh anak lebih banyak dan tata bahasanya lebih teratur. Kata-kata yang diujarkan tidak hanya 2-3 kata saja, melainkan lebih dari itu. Demikian juga terjadi pada subjek penelitan, yang mana sudah banyak kata yang diujarkan, walupun ujarannya belum begitu jelas. Sedangkan pada usia 5-6 tahun, bahasa yang digunakan oleh anak sudah menyerupai bahasa orang dewasa (Fatmawati, 2015). Oleh karena itu perkembangan akan terus terjadi dari sejak lahir yang terus berkembang seiring dengan bertambahnya usia hingga meninggal.

Berkembangnya bahasa yang digunakan tersebut dipengaruhi oleh faktor lingkungan, baik lingkungan keluarga maupun masyarakat. Misalnya, sih anak pada waktu berdialog dengan orang tua dan orang-orang di sekitar rumahnya dia mendengarkan kalimat-kalimat yang baru dia dengar kemudian ia menyimpannya di dalam pikiran, sehingga pada suatu saat kalimat-kalimat itu dibutuhkan maka sih anak akan menuturkannya. Oleh sebab itu, pergaulan atau kegiatan berbahasa yang dilakukan di lingkungan keluarga maupun masyarakat mempengaruhi berkembangnya suatu bahasa, karena pada dasarnya sejak kecil manusia sudah terbiasa meniru apa yang dilakukan seseorang di sekitarnya. Demikianpun meniru dalam kegiatan berbahasa.

Pada penelitian ini, penulis menggunakan objek anak yang berusia 3 tahun bernama Ahmad Sidratul Muntaha. Ia biasa dipanggil dengan Ahmed. Ahmed adalah anak ketiga dari tiga bersaudara dari pasangan Bapak Muhammad Utomo dan Ibu Siti Roimah. Ahmed lahir di Ciputat Timur, Tangerang Selatan. Ahmed adalah anak yang sangat aktif, baik dalam bertingkah laku ataupun bercakap di keluarga dan lingkungan tempat tinggal. Di lingkungan kelurga yang sehar-hari memakai bahasa ibu, baik orang tua, kakak, paman sering melatih dia untuk mengucapkan kata-kata yang masih belum jelas pengucapannya, sehingga lama kelamaan dia bisa mengucapkan kata tersebut dengan pelafalan yang benar. Di lingkungan tempat tinggal, Ahmed bermain dengan teman-teman yang berusia lebih tua darinya, dari umur 5-9 tahun yang mana pada usia ini, rata-rata ucapan yang dituturkan seperti orang dewasa, baik dalam segi pelafalan, susunan kalimat dan intonasi. Dengan adanya faktor-faktor tersebut, kata-kata yang disimpan oleh Ahmed sudah cukup banyak bahkan intonasi juga sudah terbiasa ia gunakan untuk mengekpresikan suatu perasaan. Oleh karena itu, perkembangan bahasa, dapat dipengaruhi oleh faktor ligkungan kelurga dan sosial yang dalam perkembangan bahasanya yang dituturkan atau diucapkan pada saat berdialog dengan lawan bicaranya. Penelitian ini bertujuan untuk mengetahui kemampuan berdialog pada anak yang berusia 3 tahun dan kalimat yang dituturkan dengan lawan bicara.

\section{METODE}

Metode yang digunakan pada penelitian ini adalah menggunakan metode kualitatif. Metode kualitatif merupakan suatu pendekatan yang mengutamakan masalah proses dan persepsi atau makna. Pada penelitan menggunakan metode ini, diharapkan bisa mengungkapkan berbagai informasi kualitatif berupa deskripsi atau analisis yang teliti sehingga penelitian memiliki makna yang penuh (Aman, 2007).

Sumber data yang digunakan pada penelitian ini adalah berupa suara rekaman anak berusia 3 tahun bernama Ahmad Sidratul Muntaha yang bertempat tinggal di Jl. Jambu, RT 002/011, Kelurahan Pisangan, Kecamatan Ciputat Timur, Tangerang Selatan, 15419. Kemudian untuk teknik pengambilan data dilakukan dengan wawancara atau dialog secara langsung untuk mengetahui kemampuan berdialog berupa kalimat-kalimat yang dituturkan pada saat wawancara. Hasil rekaman wawancara tersebut, kemudian 
Ifan Setiawan

Kemampuan Berdialog pada Anak Usia 3 Tahun

diubah menjadi suatu data yang berupa tulisan sehingga mudah untuk dianalisis.

\section{HASIL DAN PEMBAHASAN}

Data 1:

Peneliti: Ahmedmau pilih gelas yang mana?

Objek: Mmmm, balu.

Peneliti: Warnanya apa itu?

Objek: Wananya putih. Nih wananya ungu. Tu tu wananya bilu! (nada tinggi)

Pada dialog pertama, menjelaskan dia$\log$ yang dilakukan oleh peneliti dengan Ahmed sebagai objek penelitian. Dialog tersebut, menggambarkan proses dialog dengan tema pembicaraan mengenai warna gelas yang ingin digunakan.

Berdasarkan dialog di atas, terlihat bagaimana objek dapat merespon dengan baik apa yang ditanyakan oleh lawan dialognya. Oleh karena itu, bisa dikatakan bahwa objek paham mengenai kalimat tanya yang biasa dilakukan pada dialog dengan baik. Selain pada hal tersebut, dalam menjawab pertanyaan peneliti, objek sudah menggunakan kosa kata yang cukup banyak dan pilihan kata yang sesuai dengan jawaban pertanyaan, bahkan objek menjelaskan jawaban yang lebih luas di luar jawaban dari pertanyaan diikuti dengan intonasi yang bernada tinggi pada akhir dialog, walaupun pengucapan pada struktur kata ada yang kurang jelas, yakni hilangnya fonem $/ \mathrm{r} /$ dan mengantinya dengan fonem /l/ pada kata warna dan baru.

\section{Data 2:}

Peneliti: Ahmed tadi main kemana?

Objek: Main mpat Iqbal.

Peneliti: Ngapain kesono?

Objek: Main tama Aka sama Iqbal.

Pada dialog kedua, menggambarkan proses dialog dengan tema pembicaraan mengenai dimana dan dengan siapa objek bermain.

Berdasarkan dialog di atas, terlihat bagaimana objek merespon dengan baik apa yang ditanyakan oleh peneliti. Oleh karena itu, bisa dikatakan bahwa objek bisa memahami kalimat tanya yang ditanyakan oleh peneliti dengan baik. Kemudian, objek dalam menjawab pertanyaan peneliti bisa memilih pilihan kata yang tepat untuk menjawab pertanyaan peneliti, sehingga jawabannya tidak membingungkan. Selain pada hal tersebut, terdapat struktur kata yang diucapkan kurang jelas atau tidak lengkap pengucapannya sesuai dengan kata yang benar. Struktur kata tersebut adalah kata tempat yang diucapkan mpat dan kata sama yang diucapkan dengan tama, di mana pada kata ini objek menghilangkan fonem $/ \mathrm{t} /$, /e/, dan $/ \mathrm{s} /$.

Data 3:

Objek: Aku mau, mau ambil itu! (nada memerintah)

Peneliti: Namanya apa?

Objek: Namanya? Hadoh.

Peneliti: Hadroh.

Objek: Hadoh. Ambil! (mengulangi)

Pada dialog ketiga, menggambarkan proses dialog dengan tema pembicaraan mengenai perintah objek kepada peneliti untuk mengambilkan sesuatu. Kemudian peneliti merespon dengan menanyakan apa yang objek ingin ambil.

Setelah objek merespon pertanyaan, objek menjawab dengan baik dengan ditandai penyebutan benda yang ia inginkan, walaupun objek sempat memikirkan terlebih dahulu benda apa yang dia inginkan dan setelah dia menemukan kata yang cocok dalam pikirannya, objek mengucapkan istilah benda tersebut dengan tepat namun, kurang jelas. Hal ini dilihat dari hilangnya bunyi fonem /r/ pada kata hadroh. Oleh karena itu, bisa dikatakan bahwa objek bisa memahami kalimat tanya yang ditanyakan oleh peneliti dengan baik. Kemudian, objek dalam menjawab pertanyaan peneliti bisa memilih pilihan kata yang sesuai untuk dia pakai ketika menjawab pertanyaan peneliti, sehingga jawabannya tidak membingungkan.

Data 4:

Peneliti: Katanya kita mau main rebana, jadi ngak?

Objek: Engga lah!

Peneliti: Kenapa?

Objek: Aku gi main handpone. 
Ifan Setiawan

Kemampuan Berdialog pada Anak Usia 3 Tahun

Pada dialog keempat, menggambarkan proses dialog dengan tema pembicaraan mengenai penolakan objek terhadap ajakan yang dilakukan oleh peneliti. Penolakan tersebut dikarenakan objek sedang bermain telepon.

Berdasarkan dialog di atas, terlihat penolakan yang dilakukan oleh sih objek yang dikuti dengan nada tinggi. Hal ini dibuktikan dengan partikel lah yang biasanya digunakan untuk menekankan makna kata sebelumnya. Kemudian selain pada hal tersebut, objek juga dapat merespon dengan baik apa yang ditanyakan oleh lawan dialognya, walaupun sih objek dalam mengucapkan katanya kurang jelas. Hal ini ditandai juga dengan kurangnya bunyi fonem /1/ dan /a/ pada kata lagi. Oleh karena itu, bisa dikatakan bahwa objek bisa menggunakan nada tinggi untuk menekankan sesuatu dan mampu memahami kalimat yang ditanyakan oleh peneliti dengan baik walaupun pengucapannya ada yang kurang jelas.

\section{Data 5:}

Peneliti: Emang mas Ipan kuliah?

Objek: Iya (nada tinggi). Aku tunggu Ipan macih lama Ipan, ya dah aku main handpone ajah, begitu.(nada tinggi)

Pada dialog kelima, menggambarkan proses dialog dengan tema pembicaraan mengenai alasan mengapa objek tidak mau bermain dengan peneliti karena manurut objek sudah cukup lama menunggu peneliti, oleh karena itu objek memilih untuk bermain telepon saja.

Berdasarkan dialog di atas, terlihat penolakan yang dilakukan oleh objek yang ikuti dengan nada tinggi pada kata iya dan begitu. Kemudian selain itu, objek juga dapat merespon dengan baik apa yang ditanyakan oleh lawan dialognya, walaupun objek dalam mengucapkan katanya kurang jelas. Hal ini ditandai juga dengan pelafalan bunyi fonem /s/ yang diganti dengan fonem /c/ pada kata macih yang seharusnya masih dan kurangnya pelafalan bunyi fonem /u/ pada kata udah. Oleh karena itu, bisa dikatakan bahwa objek bisa menggunakan nada tinggi dan memahami kalimat tanya yang ditanyakan oleh peneliti dengan baik walaupun pengucapan struktur katanya ada yang kurang jelas.

\section{Data 6:}

Peneliti: Lagi makan apa tuh orangnya?

Objek: Tuh, mak ciki-ciki.

Peneliti: Coba cari yang lain!

Objek: Ni ajah (nada tinggi)

Peneliti: Emang Ahmet suka?

Objek: Iyalah ku cuka inih.

Peneliti: Kuenya warna apa itu?

Objek: Wana itu, wana putih.

Pada dialog keenam, menggambarkan proses dialog dengan tema pembicaraan objek dan peneliti sedang menonton tayangan di pranala Youtube. Kemudian peneliti menanyakan apa yang sedang objek lihat. Berdasarkan dialog di atas, terlihat bagaiamana secara keseluruhan dialog dapat dijawab dengan baik dan benar oleh objek. Respon dalam mejawab pertanyaanpun juga demikian. Namun, objek dalam mengucapkan jawabannya ada beberapa kata yang kurang jelas, seperti kata mak yang seharusnya makan, hal ini dikarenakan ketika menjawab pertanyaannya dengan cepat. Kemudian, fonem /s/ yang diganti dengan fonem /c/ pada kata suka dan fonem /r/ yang tidak ada pada kata warna. Hal ini wajar saja terjadi, karena memang huruf konsonan $s$ dan $r$ memang sulit diajarkan kepada anak, karena anak sulit menirukan dan melihat penempatan lidah pada alat ucap untuk mengucapkan fonem /s/ dan /r/ ketika diajarkan. Hal ini bisa disebabkan oleh faktor lingkungan yang mungkin tidak mengajarkan pelafalan bunyi secara benar dan terus menerus. Oleh karena itu, bisa dikatakan bahwa objek bisa menggunakan intonasi nada dan memahami kalimat tanya yang ditanyakan oleh peneliti dengan baik walaupun pengucapannya ada yang kurang jelas karena kesulitan mengucapkan fonem. 
Ifan Setiawan

Kemampuan Berdialog pada Anak Usia 3 Tahun

Data 7:

Peneliti: Itu apa?

Objek: Nih Gulk nih Sidemen

Peneliti: Itu Hulk satunya Spiderman?

Objek: Iya.

Peneliti: Itu lagi ngapain?

Objek: Lagi capu.

Peneliti: Sapu? Nyapu.(mengajarkan)

Pada dialog ketujuh, menggambarkan proses dialog dengan tema pembicaraan objek dan peneliti yang sedang menonton tayangan di pranala YouTube. Kemudian peneliti menanyakan apa yang sedang objek tonton.

Berdasarkan dialog $\mathrm{di}$ atas, terlihat bagaiamana secara keseluruhan dialog dapat dijawab dengan baik oleh objek. Respon dalam mejawab pertanyaanpun juga demikian. Namun, objek dalam mengucapkan jawabannya ada beberapa kata yang kurang tepat, seperti kata dalam bahasa asing sebagai kata ganti seorang pahlawan dalam film, yakni Hulk dan Spiderman, namun objek mengucapkan dengan kata Gulk dan Sideman. Hal ini bisa dikarenakan faktor lingkungan maupun sosial masyarakat yang tidak terbiasa dengan pengucapan bahasa asing, karena memang dilingkungan keluarga dan lingkungan tempat tinggal objek jarang sekali mengucapkan kata dalam bahasa asing, melainkan dominan menggunakan bahasa ibu. Sehingga, objek sulit untuk mengucapkan atau menirukan kata tersebut. Kemudian selain itu, objek juga mengubah bunyi fonem /s/ dengan bunyi fonem /c/ pada kata sapu yang menjadi сари. Hal ini tentu wajar saja terjadi, karena memang huruf konsonan $s$ sulit diajarkan kepada anak, apalagi anak yang berusia 3 tahun karena sulit menirukan dan melihat penempatan lidah pada alat ucap untuk mengucapkan fonem /s/ ketika diajarkan. Hal ini bisa disebabkan oleh faktor lingkungan yang mungkin tidak mengajarkan pelafalan bunyi secara benar dan terus menerus. Oleh karena itu pada dialog tersebut, bisa dikatakan bahwa objek bisa memahami kalimat tanya yang ditanyakan oleh peneliti dengan baik walaupun pengucapannya ada yang kurang jelas karena kesulitan mengucapkan bunyi fonem yang asing didengar dan susah untuk ditirukan.

\section{Data 8:}

Peneliti: Kemarin ke tempat mamas Rama ya? Objek: Iyah.

Peneliti: Mamas Rama di mana emang?

Objek: Mas Rama ngak-ngak pulang-pulang. (nada panjang)

Pada dialog kedelapan, menggambarkan dialog dengan tema pembicaraan menanyakan Kakak kandung objek yang tidak berada di rumah. Oleh karena itu, peneliti menanyakan kepada objek yang beberapa hari lalu menjenguk Kakaknya di pondok pesantren.

Berdasarkan dialog di atas, terlihat bagaiamana dialog dapat dijawab dengan baik oleh objek. Respon dalam menjawab pertanyaanpun juga demikian. Namun, pada kalimat jawaban yang terakhir struktur kata yang diucapkan objek tidak tepat. Hal ini, terlihat bagaimana objek mengulang-ulang kata ngak untuk membenarkan kata sebelumnya. Selain itu kata ngak merupakan bahasa yang digunakan oleh masyarakat perkotaan begitupun di lingkungan tempat tinggal objek, sebagai kata ganti kata tidak dalam bahasa baku bahasa Indonesia. Sehingga faktor mengapa kata ngak digunakan oleh objek adalah karena meniru atau berasal dari faktor lingkungan keluarga ataupun lingkungan tempat tinggal di sekitar rumah objek. Maka dari itu, faktor lingkungan keluarga dan masyarakat, juga menentukan pemerolehan bahasa yang digunakan oleh anak. Dapat disimpulkan, bahwa pada dialog tersebut objek bisa memahami kalimat tanya yang ditanyakan oleh peneliti dengan baik walaupun ada beberapa struktur kata yang diulang untuk menekankan kata tersebut lebih jelas yang kata tersebut digunakan karena faktor lingkungan internal maupun eksternal.

\section{KESIMPULAN}

Berdasarkan pembahasan yang telah dilakukan, maka dapat disimpulkan bahwa objek memiliki suatu kemampuan berbahasa, khususnya berbicara atau dialog yang baik. Walaupun ada beberapa pengucapan bunyi pada kata yang dia ganti karena sulit untuk mengucapkan, diantaranya pada bunyi fonem /s/ dan /r/. Hal ini bisa dilihat dari pola-pola 
kalimat pada setiap dialog ketika subyek diberikan suatu pertanyaan oleh peneliti. Baik dilihat dari ketika objek merespon dengan cepat dan tepat, sehingga jawabannya tidak ambigu atas apa yang ditanyakan oleh peneliti. Kemudian intonasi pada saat menekankan suatu kata maupun kata-kata yang digunakan sudah cukup banyak diucapkan layaknya orang dewasa. Oleh karena itu, dapat dikatakan bahwa objek memperoleh banyak pembendaharan kata yang tentu dipengaruhi oleh faktor lingkungan keluarga dan sosia masyarakat.

\section{SARAN}

Penulis memiliki saran bagi pembaca terkait dengan penelitian ini, yakni:

1. Penelitian ini dapat digunakan sebagai referensi dalam suatu penelitan mengkaji ilmu dalam bidang psikolinguistik sebagai kajian yang cukup baru.

2. Penelitian ini dapat digunakan sebagai bahan pembelajaran untuk menambah pengetahun bagi kalangan akademisi maupun masyarakat terkait dengan seluk-beluk proses pemerolehan bahasa dan perkembangan bahasa dari sejak lahir hingga dewasa.

\section{DAFTAR PUSTAKA}

Aman. 2007. "Metodologi Penelitian Kualitatif". Disampaikan dalam acara Diklat Penulisan Skripsi Mahasiswa Pendidikan Sosiologi yang diselenggarakan oleh HIMA Pendidikan Sejarah FISE UNY. Yogyakarta: 23 Mei 2007.

Aprilia, Mia Nur dan Nuryani. 2020. "Kemampuan Bercerita Pada Anak Usia 5 Tahun: Kajian Psikolinguistik". Journal Jubindo, Vol. 5 No. 1. Edisi April 2020.

Chaer, Abdul. 2012. Linguistik Umum. Jakarta: Rineka Cipta.

Susanti, Elvi. 2018. Keterampilan Berbicara. Depok: PT RajaGRafindo Persada.

Fatmawati, Suci Rani. 2015. "Pemerolehan Bahasa Pertama Anak Menurut Tinjauan Psikolinguistik". Jurnal Lentera, Vol. XVIII No. 1. Edisi Juni 2015.
Kushartanti, dkk. 2009. Pesona Bahasa: Langkah Awal Memahami Linguistik. Jakarta: Gramedia Pustaka Utama.

Nuryani, Putra, Dona Aji Karunia. 2013. Psikolinguistik. Tangerang Selatan: Mazhab Ciputat.

Kamus Besar Bahasa Indonesia V Daring 